\title{
The ecological tax in Russia as the economic instrument of the environmental protection
}

\author{
Galina Semenova ${ }^{1,2, *}$ \\ ${ }^{1}$ Moscow Region State University, Radio str, 10A, 105005, Moscow, Russia \\ ${ }^{2}$ Plekhanov Russian University of Economics, Stremyanny lane 36, 117997, Moscow, Russia
}

\begin{abstract}
The relevance of article is determined by the fact that one of the main wealth of Russia is the set of its natural resources and its environment. Nowadays, the rational and careful use of the environment and its wealth become the important objectives facing the countries of the world. Global deterioration in the ecological situation puts the problem of transition to the waste-free or low-waste production technology before the mankind. The subject of this research is the ecological tax as the economic instrument of environmental protection and efficient environmental management. The key indicators characterizing the impact of business activities on the environment and natural resources (such as dumping of the polluted sewage, emissions of pollutants in atmospheric air, water intake from the natural water objects for the use for the period from 1992 to 2017) were systematized. The author proved the expediency of introduction of the ecological tax. Some criteria for the evaluation of optimality of the ecological taxation were offered. Comparative, economical and statistical methods of the analysis were used for the justification of the conclusions. The results of the research can be used in the sphere of the improvement of the tax legislation of the Russian Federation and also for the modernization of the environmental policy of Russia during planning and implementation of the measures directed to the increase in the efficiency in the sphere of environmental management and environmental protection.
\end{abstract}

\section{Introduction}

Scientists all over the world dealt with the environmental problems, so the great contribution to the formation of ecological knowledge was made by the Swedish scientist K. Linney, the American ecologist V.Yu. Odum published one of the best textbooks on ecology, "Fundamentals of ecology". The German ecologist E. Gekkel for the first time used the term "ecology" in its modern understanding. Works of the famous biologists K.F. Rulye and N.A. Severtsev were of great importance for the development of ecology in Russia. The modern period of epy development of ecology in the world is connected with many scientists names. It is necessary to cite I.P. Gerasimov, A.M. Gilyarov, V.G. Gorshkov, Yu.A. Izrael, Yu.N. Kurazhskovsky, K.S. Losev, N.N. Moiseyev, Ya.P. Naumov, N.F. Reymers, V.V. Rozanov, Yu.M. Svirikev, V.E. Sokolov, V.D. Fedorov and others among the domestic scientists.

\footnotetext{
* Corresponding author: Sg6457@mail.ru
} 
Resources of the environment are not unlimited, that is proved by its use as the "garbage can" in spite of its limited ability to take waste, harmful substances, etc. Sometimes behind the profit pursuit the enterprises cut down trees, that influences animals and flora. It is necessary to utilize, process waste, but they are dug in, it affects quality of soils, this interrelation includes terrible garbage power plant as well. This is the negative external impact which is shown in causing damage to the environment. The analysis of the results of external impact of production proves, that in case of air pollution, waters, soils or noise harm is done to the environment and the irreplaceable natural resources in consumption are exhausted as well. It is easy to cause extensive damage to the nature, but it will be required to restore it for long. Air pollution, waters and soils proved, that the environment cannot be used unlimitedly. Many experts consider, that the nature is used as a free or cheap resource. For example, iron ore, oil, coal, gas among the used natural resources are exhausted, the wood, fauna are renewed. The growing deficiency of many resources negatively affects not only consumption, but also production. Many enterprises try to save on the treatment facilities, but it is necessary to understand, that if there is no environment, which is enough high quality, as a factor of production, then costs of carrying out even of expensive actions for its cleaning can quickly exceed the seeming profits on refusal of the use of preventive ecological actions. At worst the environmental pollution by certain industries can harm other industries. The greatest loss of indicators comes from the impact of the industry, which release a large number of harmful wastes into the atmosphere. Because of it there is a special type of climate in the cities, where acid rains drop out, the smog is felt, all this badly affects the human health.

\section{Materials and Methods}

In Russia the enterprises of ferrous and nonferrous metallurgy, pollute the environment with heavy metals. But coal mining and oil extraction, energetics, military industrial complexes, production of industrial materials are recognized to be the most ecologically dangerous industries. The key indicators, characterizing the impact of economic activity on the environment and natural resources, are presented in Table 1.

Table 1. Key indicators, characterizing the impact of economic activity on the environment and natural resources [4].

\begin{tabular}{|c|c|c|c|c|c|c|c|c|c|}
\hline & 1992 & 2000 & 2005 & 2010 & 2013 & 2014 & 2015 & 2016 & 2017 \\
\hline $\begin{array}{l}\text { Water intake from natural } \\
\text { water objects for the use }{ }^{1)} \text {, } \\
\text { billion } \mathrm{m}^{3}\end{array}$ & 99.6 & 75.9 & 69.3 & 69.7 & 61.0 & 63.2 & 60.8 & 61.3 & ... \\
\hline $\begin{array}{l}\text { Dumping of the polluted } \\
\text { sewage }^{1)} \text {, billion } \mathrm{m}^{3}\end{array}$ & 27.1 & 20.3 & 17.7 & 16.5 & 15.2 & 14.8 & 14.4 & 14.7 & ... \\
\hline $\begin{array}{l}\text { Emissions of pollutants in } \\
\text { atmospheric air, million } t \text {. }\end{array}$ & 50.2 & 32.3 & 35.8 & 32.3 & 32.0 & 31.3 & 31.3 & 31.6 & 32.1 \\
\hline - from stationary sources ${ }^{2}$ & 28.2 & 18.8 & 20.4 & 19.1 & 18.4 & 17.5 & 17.3 & 17.3 & 17.5 \\
\hline - from mobile sources ${ }^{3)}$ & 22.0 & 13.5 & 15.4 & 13.2 & 13.6 & 13.8 & 14.0 & 14.3 & 14.6 \\
\hline $\begin{array}{l}\text { Formation of industrial and } \\
\text { consumption waste }{ }^{4} \text {, } \\
\text { million t. }\end{array}$ & $\ldots$ & 128 & 3036 & 3735 & 5153 & 5168 & 5060 & 5441 & 6221 \\
\hline
\end{tabular}

1) According to Rosvodresursy.

2) Since 2013 - including individual entrepreneurs.

3) Since 2010 - according to Rosprirodnadzor; emissions from motor and railway transport, 1992, 2000, 2005 - according to former Ministry of natural resources of the Russian Federation; emissions from the motor transport. 
4) Since 2010 - according to Rosprirodnadzor; 2005 - according to Rostekhnadzor. Since 2005 industrial and consumption waste; 2000 - toxic waste.

Table 1 demonstrates, that all the indicators of impact of economic activity on the environment and natural resources increase, especially the indicator "formation of industrial and consumption waste" does, its gain makes $14.3 \%$.

According to professor D.N. Dorogutina, in case of the decline in production by $70 \%$ the emissions of pollutants in the atmosphere will decrease only by $12 \% .70 \%$ of superficial and $30 \%$ of underground waters lost the drinking value [1]. Economic damage from irrational environmental management in the developed foreign countries are assessed as 4-8\% of GNP. For Russia the assessment of total damage makes $15-17 \%$ of GNP approximately.

Calculation of the annual economic damage from the pollution of atmospheric air $\left(\mathrm{P}_{\mathrm{atm}}\right.$. is made according the formula:

$$
\sum_{i=1}^{n} P_{a t m}(t)=\gamma * \sigma * f * \sum A_{i} * m i t
$$

where, $\gamma$ - monetary assessment of a unit of emissions, roubles per a ton of conditional fuel. This volume has to consider inflationary processes therefore it is not constant. The base is $\mathrm{SO} 2$ ( $1 \mathrm{t}$ of $\mathrm{SO} 2=1$ ton of conditional fuel);

$\mathrm{t}$ - time frame (year);

$\sigma$-coefficient, allowing to consider regional features of the territory, which is the subject to harmful effects (it is undertaken from special tables);

$\mathrm{f}$ - the amendment, considering the nature of dispersion of impurity in the atmosphere (undertaken from special tables). If there is no gas-cleaning equipment or the extent of cleaning less than $70 \%$, then $\mathrm{f}=3$; if the efficiency of cleaning $=70-90 \% \mathrm{f}=2.5$ and if the efficiency of cleaning is more than $90 \% \mathrm{f}=2$. For gaseous substances and aerosols $\mathrm{f}=1$;

$A_{i}$ - coefficient of reduction of impurity of $i_{\text {th }}$ type to "monopollutant", ton of conditional fuel;

$m_{i t}-$ emission volume of the $i_{\text {th }}$ type of impurity of pollutant (during an year, $t$ ).

Economic assessment of annual size of damage to reservoirs $\left(\mathrm{P}_{\text {water }}\right)$ it is carried out according to the formula:

$$
\sum_{i=1}^{n} P_{\text {water }}(t)=p t * \beta * \sum D_{i} * V_{i t}
$$

where, $\rho t$ - monetary assessment of dumping unit into rub per one ton of conditional fuel;

$\mathrm{t}$ - time period (year);

$\beta$ - coefficient, allowing to consider features of a reservoir, which is subject to harmful effects;

$D_{i}$ - coefficient of reduction of impurity of the $i_{\text {th }}$ type to "monopollutant", per one ton of conditional fuel;

$\mathrm{V}_{\mathrm{it}}$ - dumping volume of the $\mathrm{i}_{\text {th }}$ type of impurity of pollutant (during one year period, $t$ ).

According to the published report of the Ministry of natural resources of the Russian Federation in May, 2017 about the course of realization and assessment of efficiency of the state programme "Environmental protection for 2012-2020" for 2016, target values of a large number of key indicators were not reached.

For example, in 2016 the emissions of pollutants in the atmosphere from stationary sources in the energy industry and metallurgy, made $80-81 \%$ of the level of 2007 at the target value of $71-72 \%$ planned in the program. Emissions of pollutants in the atmosphere from the motor transport made $94 \%$ instead of the planned $83 \%$. In general, 17.4 million people lived 
in Russia in the territories with an adverse ecological situation last year as a result of last economic and other activity (the planned value for 2016 - 17.2 million people) [2].

All this, is connected with the reduction of financing of nature protection actions, both from business, and from the state. At the same time the level of the current costs of environmental protection slightly deviated the planned value in 2016 (about 172\% of the level of 2007 in comparison with the planned 173\%). According to the international organization, 944 people per 1 million inhabitants in Russia died in 2015 because of air pollution by these substances. For comparison, in 1990 this indicator in Russia was lower and made up 910 people per 1 million inhabitants. The average value for the countries of OECD was in 2015 at the level of 393 people per 1 million inhabitants in 2015 [3].

\section{Results}

The ecological line of the tax policy in Russia was not so consecutive. The ecological federal tax was originally included in the Tax Code of the Russian Federation, but it was not put into operation. In 2014, when Federal law No. 219-FZ "On introduction of amendments to the Federal law "On Environmental Protection" and separate acts of the Russian Federation" was adopted on 21.07.2014, the reform in the ecological sphere began. Nowadays the following actions are considered in Russia as the negative impact on the nature: placement of waste; emissions in the atmosphere of harmful substances by stationary facilities (pipes of the plants, boiler houses, diesel installations, cutting and welding of metals, etc.); pollution of water resources dumping; harming soil and subsoil of the earth. Now provisions on the payment for negative impact on the environment are enshrined in the law "On Environmental Protection" No. 7-FZ, adopted on 10.01.2002. Its size depends on the volume of emissions of pollutants. The payment for harming of ecology is transferred to the budget once a year by subjects of small and medium business; once a quarter in the form of the amounts of advance payments by other payers. Stationary facilities (located on the earth, the harmful substances polluting the soil or throwing out in air; facilities on which waste is placed (dump, ground, storage, etc.) are allocated into four groups depending on their negativity (their action on the ecology): group 1 - considerable; group 2 - moderate; group 3 - insignificant; group 4 - minimum. The facilities, relating to the group 4 are exempted from payments. The amount of a payment is set within admissible standards, within limits and over limits.

The amount of payment within admissible standards is specified as follows:

Norm rate * Volumes of pollution* Additional coefficients.

The amount of payment within limits is specified as follows:

Limit rate * (Volume of pollution limit - Volume of pollution within admissible standards) * Additional coefficients.

The amount of payment for pollution over limits is specified as follows:

Limit rate * (Actual volume of pollution - Volume of limit pollution) * Additional coefficients $* 5(25)$.

For superlimit environmental pollution the amount of payment is to increase 5 (25) times.

The enterprise include the sum of collecting in the expenses during calculation of taxable profit, and the excess indicators are paid from net profit. But the amount of payment can decrease at the expense of the deductions, representing the sum of costs of the decrease in the polluting impact on the environment and applications to rates of payment of the stimulating coefficients. Temporary standards (limits) are also taken into account in certain cases. If large business is engaged in placement of waste, it has to provide the project of placement of waste in Rosprirodnadzor. It is optional for the small and medium business, placing waste to develop the corresponding projects, they report to the Department on the activity, which is followed by emissions of harmful substances in the environment. 
The Ministry of Finance of the Russian Federation developed the project of changes in the Tax Code of the Russian Federation, providing introduction of a new ecological tax which will be paid by individual entrepreneurs and the enterprises. The ecological tax has to replace the operating payments for environmental pollution: dumping of pollutants into sewage and into water objects within standards of admissible emissions, standards of admissible norms; emissions of pollutants into atmospheric air; placement of industrial and consumption waste within the set limits on their placement. Therefore the enterprises have to take measures for the protection of ecology and to indemnify the caused damage besides payment of collecting. They should introduce new innovative technologies for the increase in the environmental efficiency. The use of the environmental professionals services will allow to lower the rate on the ecological tax. And if business is not attentive to the solution of the environmental issue, it will be expensive to manage. Nowadays the situation on investments in Russia is getting much better, and the increasing number of the enterprises is put by the investments into fixed capital, directed to environmental protection and rational use of natural resources, as shown in Table 2.

Table 2. Investments into fixed capital, directed to environmental protection and rational use of natural resources* (in actual prices; mln rubles; 1992 - bln rubles) [3].

\begin{tabular}{|l|c|c|c|c|c|c|c|c|c|}
\hline & 1992 & 2000 & 2005 & 2010 & 2013 & 2014 & 2015 & 2016 & 2017 \\
\hline Total & 53 & $\begin{array}{c}2233 \\
9\end{array}$ & $\begin{array}{c}5873 \\
8\end{array}$ & $\begin{array}{c}8909 \\
4\end{array}$ & $\begin{array}{c}12380 \\
7\end{array}$ & $\begin{array}{c}15863 \\
6\end{array}$ & $\begin{array}{c}15178 \\
8\end{array}$ & $\begin{array}{c}13967 \\
7\end{array}$ & $\begin{array}{c}15299 \\
6\end{array}$ \\
\hline $\begin{array}{l}\text { Including } \\
\text { protection } \\
\text { of: }\end{array}$ & & & & & & & & & \\
\hline $\begin{array}{c}\text { - water } \\
\text { resources }\end{array}$ & 33 & 8251 & $\begin{array}{c}2614 \\
3\end{array}$ & $\begin{array}{c}4602 \\
5\end{array}$ & 59505 & 76315 & 78962 & 67469 & 65863 \\
\hline $\begin{array}{c}\text { - atmosphe } \\
\text { ric air }\end{array}$ & 9.2 & 7946 & $\begin{array}{c}1983 \\
9\end{array}$ & $\begin{array}{c}2612 \\
7\end{array}$ & 41196 & 55587 & 40120 & 40340 & 59827 \\
\hline - lands & 7.1 & 3520 & 9206 & 9340 & 13802 & 14540 & 15703 & 12228 & 10174 \\
\hline
\end{tabular}

* Since 2005 - without VAT.

The new ecological tax has to be directed to the increase in environmental efficiency. The main distinction of the new ecological tax from the old payment for negative impact on the environment is in the mechanisms of the tax charge [4]. According to the data of production environmental control for each facility, for each stationary source and for each pollutant, to strictly certain hazard class of this substance (tax base) is specified by the taxpayer. At the same time the ta [payer have to consider the volume of emissions of pollutants, dumping of pollutants within limits on emissions and dumping of pollutants and microorganisms; the volume of emissions of pollutants, dumping of pollutants exceeding standards; the volume of emissions of pollutants, dumping of pollutants within standards of admissible emissions, standards of admissible dumping; limits on placement of industrial and consumption waste and their excess. According to types of pollutants and the hazard class of industrial and consumption waste the sizes of tax rates are specified. Tax rates are specified in rubles per 1 ton of pollutant. For example, the rate for emission of ammonia in air equals to 138.8 rubles per 1 ton, and for methane it is 108 rubles, for hydrogen sulfide is 686.2 rubles.

The optimization of ecological collecting has to push business to respect for the environment. The increase in the tax burden for the enterprises is not supposed after the introduction of the ecological tax by the Ministry of Finance of the Russian Federation. During replacing ecological collecting by the ecological tax, its rate will not be changed. The opportunity to reduce payment of the tax on the sum of expenses on actions for the decrease in damage to the environment remains. It is considered, that if the enterprises make investments, directed to environmental protection and rational use of natural resources, it is possible to receive a tax benefit [4]. Perhaps, the budget will get less income from the tax as 
a result of the provided privileges to business, but it will be much cheaper, than to pay for restoration of the environment or natural resources. It is planned, that the money, gained for the federal budget from the ecological tax will be directed to the implementation of state programmes in the form of payment of subsidies to territorial subjects of the Russian Federation for joint financing of the ecological regional programmes, directed to the optimization of the address with waste and also compensation of costs for utilization of the goods which lost consumer properties.

Thus, the following main results were received within the conducted research:

1. The ecological tax is the most effective method of the internalization of ecological damage.

2. The most convenient criteria for the evaluation of the optimality of ecological taxation are: efficiency, equality, administration, execution of the requirements of the legislation, the use of the tax revenues.

3. Unlike the majority of fiscal tools, the ecological tax is supposed to have the adjusting impact on the economic processes. At the same time there has to be a reduction of the harmful effects on the nature, which are the tax base.

4. The system of ecological taxation in Russia considerably lags behind the European level. It is expressed first of all in the unfairly low rates of taxes, which receipts do not cover the cost for the environmental protection.

5. The improvement of the system of ecological taxation in Russia for the purpose of ensuring of sustainable ecologic-and-economic development, stimulation of the decrease in the negative impact, has to be carried out taking into account some taxation optimality criteria. It has to consist in change of nature of the existing payments and in introduction of new types of economic tools.

The achieved results of the research can be used in the sphere of improvement of the tax legislation of the Russian Federation and also for the modernization of the environmental policy of Russia during planning and implementation of the measures, directed to the increase in the efficiency in the sphere of environmental management and environmental protection.

\section{Discussion}

The opinions on introduction of the ecological tax include pros and cons. According to the CEO of Soemz JSC, the member of the supervisory board of SRO Liga of waste paper processors Association Denis Kondratyev: "Introduction of the ecological tax as the instrument of replenishment of the federal budget, leaving from the basic purpose of ecological collecting (significant decrease in percent of waste disposal on grounds by the means of the increase in a share of their processing and involvement of secondary resources in economic circulation), not only will stop growth of a new industry, but also will not allow to achieve the goal of reduction of number of grounds of solid municipal waste and, therefore, improvement of quality of life of citizens of the country" [5].

According to the Vice-Chairman of Committee on environmental problems and environmental management of the Moscow Chamber of Commerce and Industry Vladimir Alentsin "The accurate effective system of administration of the tax is necessary, for this purpose there has to be a high qualification of staff of supervisory authorities in assessment of the amount of charge of payments and charges, $100 \%$ coverage of potential payers, existence of tools for collecting payments and charges, focus of the mechanism on the solution of tasks of protection of the surrounding environment. If there is no full-fledged control system and supervision, including of the nomenclature and the number of import of goods and, therefore, the number of controlled economic entities, the correctness of charge of the ecological tax, by reliability of the reporting on utilization forms the discriminatory environment for economic activity for law-abiding economic entities". 
The Managing Director of the International Monetary Fund Christine Lagarde believes that the use of fiscal tools in the prices of energy resources is not so difficult for reflection of the damage to the environment. "It is only necessary to decide on appropriate tax base and rates proceeding from aiming at a source of damage to the environment. It means, for example, providing that collecting from different types of fuel is proportional to emissions from these types of fuel. Thus, it is necessary to establish the correct relative prices of "dirty", intermediate and "clean" types of fuel. It has to stimulate adoption of ecologically favorable decisions, like transfer of power plants on less polluting types of fuel, installation of treatment facilities, transition to more energy efficient vehicles and household appliances".

"Reforms of taxes on fuel can bring essential benefit for the population health, as well as for the environment and for the budget, - the director of the department of budgetary questions of the IMF Vitor Gaspar considers. - Transition from the existing fuel prices to the effective prices at world level would allow to reduce the mortality connected with air pollution (as a result of combustion of fossil fuel) by $63 \%$, generally due to the reduction of mortality from combustion of coal, to reduce the emissions of carbon connected with power by $23 \%$ and to gain income in the size equivalent to $2.6 \%$ of GDP".

\section{Conclusions}

Introduction of the ecological tax in Russia is proved by the need of financial support of the Government of the Russian Federation activity, connected with carrying out state policy in the field of the ecology, aimed on providing the conditions for realization by citizens of their constitutional right for the favourable environment. Receipts from the ecological tax will in turn give the need to finance ecological programs of the state by other budget revenues.

The majority of opinions come down to one of them, all of us have to make thrifty use of ecology, our health and health of many next generations depends on it. Everyone has to keep in his or her consciousness to make thrifty use of the environment and natural resources. No taxes and penalties will be able to compensate the harm that is done by humans.

The stimulating impact on the economic entities with the purpose to change their behavior, causing the environmental damage is made without the primary intention to gain any income for the state (in case of great environmental efficiency of business the receipts from the tax with a fixed rate inevitably fall if the tax is effective, and the taxable basis is reduced). The ecological tax as a source of receipts, can affect the behavior of economic entities and at the same time bring the essential income, exceeding the receipts, which are necessary for collecting of the tax. Depending on the purposes of collection of the ecological tax a definite approach to the determination of a tax rate as well as the choice of additional measures of the environmental policy can be applied. It should be noted, that the problems of the choice of adequate environmental policy are very debatable. Therefore, the ecological tax has to be directed to the increase in the environmental efficiency.

\section{References}

1. D.N. Dorogutina, Young scientist 42, 48-87 (2017)

2. Y.Morozyuk, A. Sharkova, I. Merkulina, O. Vasilyeva, Journal of Environmental Management and Tourism 8 (3-19), 507-515 ( 2017)

3. G. Dyakova, S. Izmaylova, A. Mottaeva, E. Karanina, IOP Conf. Series: Earth and Environmental Science 90, 012218 (2017) doi :10.1088/1755-1315/90/1/012218

4. I. Markina, A. Sharkova, Journal of Applied Economic Sciences 9(4), 687-693 (2014)

5. K. Kunanbayeva, A.Gorovoy, A. Butyrin, MATEC 193, 05048 (2018) 